\title{
Assessment of the Energy Potential of Chicken Manure in Poland
}

\author{
Mariusz Tańczuk ${ }^{1, *}$, Robert Junga ${ }^{1}$, Alicja Kolasa-Więcek ${ }^{2}$ and Patrycja Niemiec ${ }^{1}$ \\ 1 Faculty of Mechanical Engineering, Opole University of Technology, 45-271 Opole, Poland; \\ r.junga@po.opole.pl (R.J.); pat.niemiec@doktorant.po.edu.pl (P.N.) \\ 2 Faculty of Natural Sciences and Technology, Opole University, 45-047 Opole, Poland; akolasa@uni.opole.pl \\ * $\quad$ Correspondence: m.tanczuk@po.opole.pl; Tel.: +48-664-475-355
}

Received: 2 January 2019; Accepted: 25 March 2019; Published: 1 April 2019

check for updates

\begin{abstract}
Animal waste, including chicken manure, is a category of biomass considered for application in the energy industry. Poland is leading poultry producer in Europe, with a chicken population assessed at over 176 million animals. This paper aims to determine the theoretical and technical energy potential of chicken manure in Poland. The volume of chicken manure was assessed as 4.49 million tons per year considering three particular poultry rearing systems. The physicochemical properties of examined manure specimens indicate considerable conformity with the data reported in the literature. The results of proximate and ultimate analyses confirm a considerable effect of the rearing system on the energy parameters of the manure. The heating value of the chicken manure was calculated for the high moisture material in the condition as received from the farms. The value of annual theoretical energy potential in Poland was found to be equal to around 40.38 PJ. Annual technical potential of chicken biomass determined for four different energy conversion paths occurred significantly smaller then theoretical and has the value from 9.01 PJ to 27.3 PJ. The bigger energy degradation was found for heat and electricity production via anaerobic digestion path, while fluidized bed combustion occurred the most efficient scenario.
\end{abstract}

Keywords: biomass; chicken manure; proximate and ultimate analysis; energy potential

\section{Introduction}

In recent years, changes in the energy policies of all member states of the European Union (EU) have been aimed at increasing the proportion of renewable energy sources (RES) in the energy supply. As a consequence of these changes, legal regulations are being introduced to increase the share of RES in the total energy balance of the European community. The efforts made by the specific governments have, accordingly, focused on the application of the common and accessible RES such as solar, wind, water and biomass. In particular, biomass, is a very promising type of RES, which demonstrates considerable diversity in terms of physicochemical properties leading to wider potential applications in the energy industry [1]. The determination of the energy potential of various types of biomass, including bio-wastes, is indispensable for the development of technologies of biomass to energy conversion as well as for effective implementation of existing technological solutions.

Poultry manure (excreta) is a problematic biomass waste. Due to the increasing concentration of poultry in holdings, the issue of removal and utilization of the manure plays an important role. Soil conditioning - the manner in which this type of manure has been predominantly utilized up to this time- - has a number of drawbacks [2], yet it has been the most popular one. This technique is applied all over the world but causes hazards to both crops and human health as a consequence of the negative effect of decomposing manure on various components of the natural environment. The effect of excessive soil conditioning can take the following forms: eutrophication, phytotoxic 
effects on succeeding crops, propagation of pathogens, pollution of atmospheric air and emission of greenhouse gases [3]. In Poland, using chicken manure as a raw material in crop fertilization as well as in mushroom cultivation are two main ways of its application and utilization. According to [4] total volume of annually generated chicken manure in Poland is enough to fertilize over $20 \%$ of crops in environmentally balanced way in terms of nitrogen concertation. It should be underlined again that massive use of poultry manure as an organic fertilizer creates a strong risk of environmental degradation due to over-fertilization. Moreover, ammonia $\left(\mathrm{NH}_{3}\right)$ atmospheric emissions from chicken manure land spreading can be several dozen times greater than emissions from combustion [5]. For this reasons it is necessary to define and apply new routes of poultry manure treatment in a sustainable way for the environment not only in Poland but in every location where these wastes are utilized mainly through soil conditioning.

One of the solutions to prevent negative environmental impact of chicken manure treatment is using it for energy generation. This can be of great interest to industry, unfortunately it is still rarely used in energy sector due to its unique chemical composition. There are several ways in which chicken manure can be used for generation of energy or for deriving improved fuel. It can be treated in such processes as fermentation (digestion), esterification, pyrolysis, gasification, co-gasification, combustion and co-combustion [3,5-7]. For more efficient energy generation it is necessary to pre-process or pre-treat chicken manure by physical and / or thermo-chemical processes such as drying, torrefaction, pyrolysis, steam treatment, and ozone treatment [6].

According to [8] chicken manure can be a promising substrate for slow pyrolysis, but the product of pyrolytic conversion should by bio-coal rather than syngas. The gasification of poultry-derived waste has been limited to laboratory and small-scale applications, whereas full and pilot scale installations operating in industrial conditions are incidentally mentioned in the literature. Experiments on gasification and co-gasification systems using both fixed and fluidized bed combustors show that to obtain a high quality fuel gas, the addition of another type of biomass or coal is desirable [9]. Combustion and co-combustion of poultry derived waste is the best known process of its thermal utilization: industrial scale installations are operated worldwide, including UK, USA, Netherlands, Ireland, Australia, Belgium, France, Germany, Italy, Spain [7], confirming the economic feasibility of the application. Despite the wide range of high-temperature thermal routes of chicken manure utilizations, in Poland only digestion processing is used so far. A raw chicken manure feedstock of $690 \mathrm{Mg} / \mathrm{h}$ supplies a biogas installation of $25-30 \mathrm{~kW}$ located directly on the farm in Pszczyna city. Incidental larger biogas units with capacity up to $1 \mathrm{MW}$ are operated in the co-fermentation mode with mixing of waste from agricultural production and processing. The way of utilizing chicken manure as a kind of alternative fuel can be of interest in particular in the countries where hard coal still forms the basic source of energy and the number of poultry producers is relatively large. Local boilers situated in the vicinity of farms appear to be an area with great potential for application of this type of biomass. The heat produced in this manner can be used for heating local buildings [10]. Advanced technologies can also be applied for distributed electricity generation on chicken farms [5].

Poland meets two basic criteria that indicate the feasibility of utilizing chicken manure for energy. The first one is associated with the considerable chicken population on farms in Poland which is a leading poultry producer in Europe. According to European Egg Processors Association (EEPA) [11], Poland was listed in fourth place among all EU states in terms of laying hens population in 2016 (11.3\% of the EU-28), next to Germany (13.7\%), France (12.6\%), Spain (11.4\%), United Kingdom $(11.0 \%)$, Italy $(10.8 \%)$ and Netherlands $(8.9 \%)$. According to Food and Agriculture Organization of the United Nations (FAO) [12], in 2016 Poland was listed in second place among all EU states in terms live chickens (12.0\% of the EU-28), next to Germany (13.0\%), France (11.9\%), United Kingdom (11.1\%), Italy $(10.1 \%)$, Spain $(10.1 \%)$ and Netherlands $(7.5 \%)$. The second one is associated with the dominant share of coal-fired sources in the production of heat: coal and coal products account for $86 \%$ of total heat production in Poland [13], similar to some other European countries where coal continues to dominate 
in the structure of the heat production system $[14,15]$. Additionally, Poland has the dominant share of coal-fired sources in the production of heat and electricity supplying chicken farms.

The latter part of this work aims to determine the quantitative and energy potential of chicken manure in Poland on the basis of the proposed methodology. Energy potential was assessed regarding two potential levels: theoretical and technical. As mentioned before, there are many technical ways for conversion chicken manure into useful forms of energy such as heat and electricity. The most common and widely used and technically advanced solutions were chosen as possible and representative conversion scenarios for the case of technical potential assessment analysis:

- biogas production through anaerobic digestion process combined with cogeneration of heat and power based on internal combustion (IC) engine,

- $\quad$ raw manure pre-drying preceding syngas generation in updraft gasification process combined with cogeneration of heat and power based on an organic Rankine cycle (ORC) module,

- raw manure pre-drying preceding combustion in fluidized-bed combustor combined with cogeneration of heat and power based on an organic Rankine cycle (ORC) module,

- raw manure pre-drying preceding combustion in fluidized-bed combustor for direct heat generation.

\section{Material, Methods and Input Data}

The total energy potential of the manure can be accessed through the weight of the manure produced by the population of birds in a given area. The features of chicken manure and considering it as a potential source of energy requires an individual approach to the assessment of their resources in the specific area (e.g., in the country). It results from the fact that the territorial distribution of chicken farms is random regarding rearing systems and their locations takes form of local territorial clusters.

The assessment of the energy potential of biomass (including chicken biomass) can be made in a number of ways [16-18]. The method of assessing this potential depends on the quantity, details and characteristics of the data available to the researcher.

From the perspective of practical application of the results, the energy potential of biomass can be classified according to the so-called potential level [19-21]. In the most common classification of the energy potential, it can be distinguish between:

- theoretical potential: volume of energy that can be useful based on the availability of equipment with 100\% efficiency (losses in the process are not accounted for), and under the assumption that the total available potential is harnessed for energy production, including specific collection factor and alternative use factor;

- technical potential: this part of the theoretical potential, which can be practically utilised, yet reduced due to technical restrictions (efficiency of available equipment, internal losses in the process, geographical location, energy storage losses). It is usually derived on the basis of detailed technical analysis;

- $\quad$ economic (market) potential: relative to fuel prices, tax rates, economic parameters and levels of subsidies. It is the part of the technical potential that can be applied after accounting for the criteria of economic tools (detailed economic analysis of profitability);

- applicable potential: energy from biomass, which can be ultimately used in energy production (usually smaller than the economic one).

\subsection{Quantitative Potential of Chicken Manure}

The total quantitative potential of chicken manure in Poland was determined as the sum of the potential of manure produced by laying hens and broilers. These two types are responsible for the majority of poultry production in Poland and were taken into account in a further analysis. Table 1 presents data on chicken population reared on Polish farms, according to the type of the rearing system. 
Table 1. Population of chicken in Poland and its provinces according to the rearing system, as of December 2017 on the basis of [22,23], in thousand.

\begin{tabular}{cccccc}
\hline \multirow{2}{*}{ Province } & \multicolumn{3}{c}{ Laying Hens } & Broilers & \multirow{2}{*}{ Overall } \\
\cline { 2 - 4 } & Cage & Litter & Free-Range & Litter & Chickens \\
\hline Dolnoślaskie (I) & 1949.7 & 414.2 & 67.9 & 3463.0 & 5894.8 \\
Kujawsko-Pomorskie (II) & 1686.6 & 226.8 & 57.9 & 9842.3 & $11,813.6$ \\
Lubelskie (III) & 1632.6 & 352.2 & 100.7 & 4469.5 & 6555.0 \\
Lubuskie (IV) & 1196.3 & 47.7 & 10.8 & 3463.0 & 4717.8 \\
ódzkie (V) & 2057.9 & 255.0 & 129.2 & 9422.7 & $11,864.8$ \\
Małopolskie (VI) & 2107.0 & 433.9 & 49.4 & 2473.6 & 5063.9 \\
Mazowieckie (VII) & 9449.1 & 842.6 & 335.6 & $27,333.0$ & $37,960.3$ \\
Opolskie (VIII) & 337.8 & 475.1 & 37.9 & 3215.6 & 4066.4 \\
Podkarpackie (IX) & 1699.0 & 367.5 & 32.6 & 3339.3 & 5438.3 \\
Podlaskie (X) & 616.7 & 690.2 & 17.2 & $11,254.8$ & $12,578.8$ \\
Pomorskie (XI) & 1481.6 & 181.6 & 55.6 & 4250.8 & 5969.6 \\
Śląskie (XII) & 1595.1 & 685.1 & 19.7 & 6170.9 & 8470.8 \\
Świętokrzyskie (XIII) & 1088.5 & 86.7 & 203.1 & 4205.1 & 5583.4 \\
Warmińsko-Mazurskie (XIV) & 913.9 & 20.8 & 29.1 & 3620.0 & 4583.8 \\
Wielkopolskie (XV) & $16,773.9$ & 554.5 & 290.0 & $17,201.2$ & $34,819.6$ \\
Zachodniopomorskie (XVI) & 1016.0 & 269.4 & 96.0 & 9947.9 & $11,329.3$ \\
Poland-overall & $45,601.7$ & 5903.3 & $1,532.7$ & $123,672.7$ & $176,710.4$ \\
\hline
\end{tabular}

The annual amount of chickens (laying hens and broilers) reared in Poland was the basis for determining the amount of manure available for energy use. For this purpose, the data on the daily production of feces (droppings) by different types of chickens was analyzed. Table 2 presents the daily production of droppings by selected chicken type. The presented data indicates that adult birds produce from 150 to $160 \mathrm{~g}$ of droppings, while young ones (pullets) produce from 65 to $110 \mathrm{~g}$. The lowest daily volume of droppings concerns broilers.

Table 2. Daily production of droppings of various types of chickens and its density [24].

\begin{tabular}{cccc}
\hline \multicolumn{2}{c}{ Chicken Type } & Daily Volume Per Bird (g) & Density of Droppings $\left(\mathbf{k g} \cdot \mathbf{m}^{-\mathbf{3}}\right.$ ) \\
\hline \multirow{4}{*}{ Pullets } & Ready to lay pullets & 100 & 605 \\
& Meat pullets & 110 & 680 \\
& Broilers & 65 & 622 \\
\hline \multirow{3}{*}{ Adult hens } & Laying hens & 150 & 650 \\
& Parent laying hens & 155 & 670 \\
& Meat chickens & 160 & 680 \\
\hline
\end{tabular}

Due to the lack of precise data, resulting from the variability of the course of hen growth (which could provide the percentage of adult hens and broilers kept on specific farms), the further calculations here have adopted the mean value of mass of manure produced by a laying hen $(110 \mathrm{~g})$ and a broiler (65 g).

The amount of manure generated by chicken farms depends not only on the mass of chicken droppings but also on the amount and type of litter (for the litter rearing system). Polish farms use straw as a litter. For the purpose of further analysis and on the basis of data collected from different Polish chicken farms, it is assumed that straw used as an additive increases the amount of litter manure by $15 \%$.

In case of broilers, the calculations were performed under the assumption that the production cycle of broilers lasts 6 weeks, followed by a shut down for maintenance of up to 3 weeks. Hence, within a year, it is possible to conduct a maximum of six production cycles taking the total time of 252 days, during which manure is produced. In the case of laying hens it was assumed that the production cycle is continuous and lasts 365 days per year. 


\subsection{Qualitative Potential of Chicken Manure}

Qualitative potential depends on physicochemical properties of the chicken manure: moisture content, ash content, volatile matter and elemental composition. Such compositional data of the manure can be derived on the basis and proximate and ultimate analysis. Performing these analyses is essential for determining the energy potential of the chicken wastes. They are also of a great importance in context of thermal destruction of poultry manure used in energy applications.

For the needs of research the samples of the manure were collected from two representative farms situated in Opole province. The first one was a large, modern holding, which specializes in rearing laying hens in the cage system and broilers on litter. The farm has a capacity of around 160,000 birds. The other one is a small farm rearing chickens in backyard system and not exceeding 1000 birds. The averaged samples from the cage system were clean manure with a high moisture level. In contrast, the samples collected from the litter system contained some addition of feathers and straw litter. The material collected from the backyard system contained manure and more feathers, straw and tree leaves. Samples from both sites were collected in November and for the control group in January.

\subsubsection{Ultimate, Proximate and Heating Value Analyses}

Collected samples were weighed and the moisture loss during pre-drying was measured at $20^{\circ} \mathrm{C}$ temperature after $24 \mathrm{~h}$ of storage. Subsequently, averaged samples were prepared and dried $105^{\circ} \mathrm{C}$ until solid mass (dry matter) was obtained. Total moisture content $\left(M_{t}\right)$ (calculated on a wet basis) was determined in accordance with the PN-EN 14774-1 standard. After drying and grinding, the samples were kept in Falcone tubes in a nitrogen atmosphere, secured by sealing with Parafilm and placed in an extractor.

Prepared samples were subjected to ultimate analysis by means of an Elementar Vario Macro Cube apparatus (Elementar Analysensysteme, Langenselbold, Germany). The concentrations of carbon $(C)$, nitrogen $(N)$, sulphur $(S)$ and hydrogen $(H)$ were measured, whereas the concentration of oxygen $(O)$ was calculated by difference. Proximate analysis manure of samples was undertaken by means of a STA 449 F3 Jupiter apparatus (Netzsch, Selb, Germany) by application of DTA/TG method [25]. The sample was heated at the rate of $50{ }^{\circ} \mathrm{C} / \mathrm{min}$ in the range of the temperatures from 80 to $1150^{\circ} \mathrm{C}$. The level of ash content $(A)$ was measured after combustion of the samples performed in the air atmosphere, while for volatile matter content $(V M)$, the analysis was performed in the nitrogen atmosphere. The concentration of the fixed carbon $(F C)$ was derived by difference.

Higher heating value $(H H V)$ was derived in an AC500 bomb calorimeter (LECO, Saint Joseph, MI, USA) in accordance with the EN-14918:2010 standard in order to determine heating value of solid biofuels. $H H V$ (in $\mathrm{kJ} \cdot \mathrm{kg}^{-1}$ ) was transformed into lower heating value in the dry state $L H V_{d}$ (in $\mathrm{kJ} \cdot \mathrm{kg}^{-1}$ ) in accordance with the common formula, in which the last term of the right-hand-side of the equation represents latent heat of water vapour formed due to hydrogen in the dry matter $\left(H_{d}\right)$, according to Equation (1):

$$
L H V_{d}=H H V_{d}-2441.8\left(9 H_{d} / 100\right)
$$

In turn, lower heating value in the wet matter was derived by converting $L H V_{d}$ in accordance with the Equation (2):

$$
L H V_{a r}=\left(L H V_{d}-24.41 M_{t}\right) \frac{100-M_{t}}{100}
$$

Table 3 presents the average results of ultimate and proximate analysis of the samples of chicken manure.

A synthetic overview of physicochemical parameters of the manure as a fuel for thermal conversion systems is presented in the paper [2], which provides an overview of the variability ranges of fixed carbon, volatile matter and ash content as well as higher heating value of dried chicken waste. These parameters vary widely, but they are characteristic of the analyzed type of biomass and depend on various factors such as nutrition, housing systems or environmental conditions 
including microclimate as well as litter type. For the purpose of this energy analysis, a distinction was made between the properties of the chicken waste from three most popular rearing systems in Poland, comparing the results obtained to the same rearing systems used in the world. The available research studies describe quite precisely the analytical composition of the manure. Unfortunately, the comparison is still difficult, because the type of rearing system, composition of bedding material or the information on whether the material has been previously processed e.g., through pre-draying, are usually not specified.

Table 3. Results of physicochemical analysis of manure for various types of poultry systems.

\begin{tabular}{|c|c|c|c|c|c|c|c|c|c|c|c|}
\hline \multirow{2}{*}{ System } & \multicolumn{4}{|c|}{ Proximate Analysis (wt. \%) } & \multicolumn{5}{|c|}{ Ultimate Analysis (wt. \%, d) } & \multicolumn{2}{|c|}{$\begin{array}{l}\text { Heating Values } \\
\left(\mathrm{MJ} \cdot \mathrm{kg}^{-1}\right)\end{array}$} \\
\hline & $M_{t w}$ & $V M_{d}$ & $F C_{d} *$ & $A_{d}$ & $C$ & $H$ & $N$ & $S$ & $O^{*}$ & $L H V_{d}$ & $L H V_{a r}$ \\
\hline Cage & 70.9 & 67.5 & 16.9 & 15.6 & 39.67 & 4.72 & 5.49 & 0.40 & 34.12 & 12.744 & 3.201 \\
\hline Litter & 18.1 & 69.9 & 18.1 & 12.0 & 42.86 & 5.57 & 5.50 & 0.68 & 33.39 & 16.546 & 13.189 \\
\hline Free-range & 54.9 & 50.4 & 5.2 & 44.4 & 21.85 & 2.50 & 1.73 & 0.28 & 29.24 & 8.577 & 3.262 \\
\hline
\end{tabular}

Parameters of the raw manure obtained from the cage system presented in Table 4 can be directly related to analyses of a battery-cage system located in Spain [26]. In both cases the moisture content $M_{t w}$ was found high, even above $70 \%$. Values of $C, H$ and $N$ content are also similar to those presented in the paper [26], that amount to $36.2 \%, 4.6 \%$ and $5.9 \%$, respectively. A significant difference concerns the element $S$. In general, its value for Spanish farms manure was about $0.1 \%$ on average. The $S$ content was $0.357 \%$ only on one of the Spanish farm, which is comparable to the results obtained in the study. The content of volatile matter $V M_{d}$ and fixed carbon $F C_{d}$ (roughly giving the organic matter) presented in Table 4, was 15 p.p. higher than mentioned in [26], which results from different analytical standards applied in both studies. The same conclusion applies to the ash content $A_{d}$, which in analyzed Polish farm is about 15 p.p. lower than for samples tested from Spanish farms. Despite these differences, the calorific value $L H V_{d}$ of the manure from cage systems is within the range reported by [26], i.e., $2660 \mathrm{MJ} \cdot \mathrm{kg}^{-1}$ on average.

In the case of manure samples from litter systems, the results of the performed analyses presented in Table 4 can be referred to more bibliographic sources. The moisture content $M_{t w}$ obtained within the research, was similar to the results reported for litter systems used in different states in the USA [10], Australia [7] and Poland [27]. However, according to [28] the moisture content of poultry litter can widely range from 9.25 to $51.8 \%$. As reported in [29] the average moisture content in the manure from farms with appropriate husbandry practices and controlled ventilation should range from 18 to $36 \%$. Bedding with a moisture content exceeding $36 \%$ increases the risk of e.g., poultry contracting cococydiosis, internal parasites or insects [29]. The content of basic elements $C, H, N$ and $S$ in the sampled manure is similar to the values recorded on Irish [28] and Polish [30] farms. Based on studies presented by Lynch et al. [28] and Toptas et al. [31] the changes of these parameters in chicken manure can be relatively wide. Lynch et al. [28] suggests that these differences may be due to the type of material bedding, litter storage conditions as well as farming practices [28]. Nevertheless, taking into account the dispersion of the elements contents, the results given in Table 4 are still in the middle of these ranges. Available publications indicate that content of volatile matter $V M_{d}$ in broiler litter varies from 53 to $75 \%$, while the fixed carbon $F C_{d}$ from 6 to $23 \%[7,10,30,32]$. It may be seen that values of $V M_{d}$ and $F C_{d}$ presented in Table 4 are comparable to those from litter raring system located in the USA [10], Turkey [32], Ireland [28] and Poland [30]. It should be noted that the manure analyzed in the study [10] and [28] contained wood shaving while the material from Poland [30] and Turkey [32] contained straw in its composition. The same levels of ash content $A_{d}$ as in presented study (approximately $12 \%$ on dry basis) were reported from other farms worldwide with wood and straw bedding materials $[10,28,31,32]$. According to Lynch et al. [28] the ash content can vary from 10.61 to 
$19.58 \%$, depending on the bedding materials. However, there are also high ash contents reported, even up to $50 \%$ [33], explained by the admixture of additional solid materials [33]. The $L H V_{d}$ of the samples from analyzed litter system (Table 3) are close to those from Turkish [32], Irish [28] and Polish [30] farms: from 15.1 to $16.7 \mathrm{MJ} \cdot \mathrm{kg}^{-1}$. In general, the values obtained from the tests are within the heating value ranges given by Lynch et al. [28].

The literature does not provide results regarding the physicochemical analysis of the manure produced in the free-range systems. In Poland, free-range systems are gaining popularity slowly, however such farms are usually more similar to the semi-intensive systems. It can explain the results of the analyses (for instance high ash content) presented in Table 3.

Figures 1-3 illustrate the results of measurements of lower heating value of manure from the farms examined as a function of their moisture content, with a comparison of the results reported in earlier works. The presented ranges of $L H V$ variation can be considered as typical of chicken manure and used to determine the energy potential of manure regardless of the place of its generation.

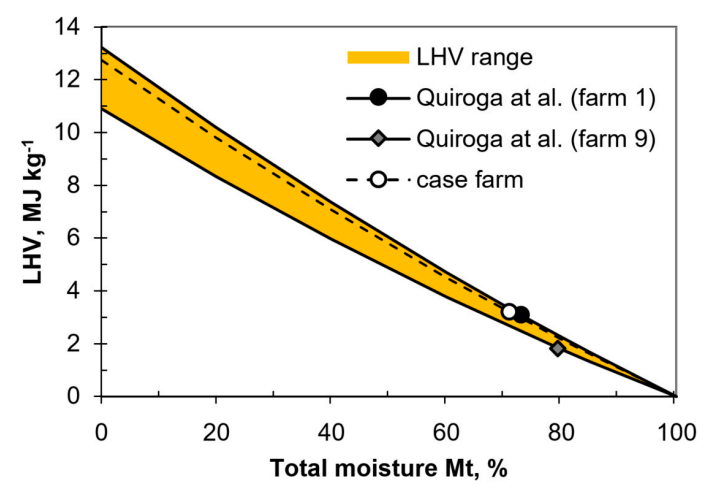

Figure 1. Lower heating value of manure from the cage system.

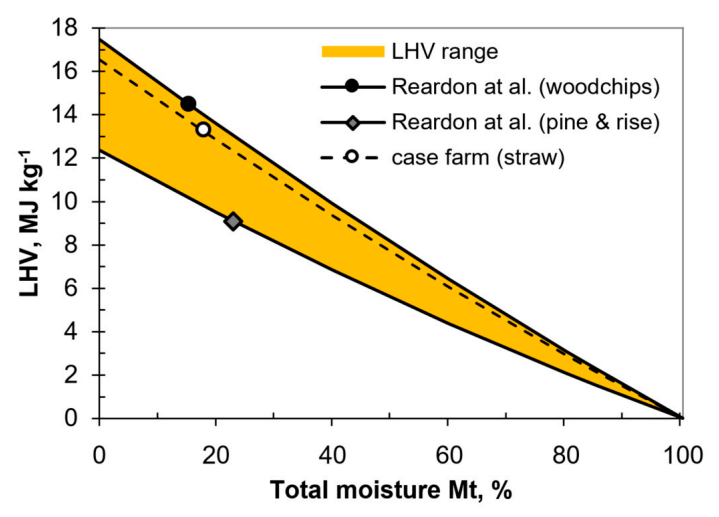

Figure 2. Lower heating value of manure from the litter system.

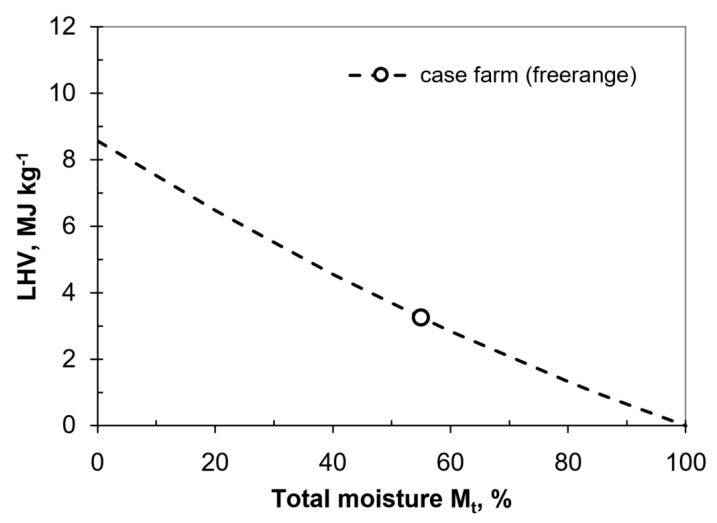

Figure 3. Lower heating value of manure from the free-range system. 


\subsubsection{Energy Potential Assessment}

The lower heating value derived in this study was subsequently applied in the procedure of assessing energy potential of chicken manure in Poland. On the basis of the determined quantitative potential of chicken manure and results of the study on lower heating value of manure, it was possible to derive the value of the energy potential for the particular provinces in Poland. The potential derived in further part of the paper is limited to two levels:

- theoretical level resulting from the overall maximum amount of chicken manure which can be considered theoretically available for energy generation within fundamental bio-physical limits,

- technical level which takes into account energy losses due to collection, transport, storage, pre-treatment (for example drying) and energy conversion from the fuel to the useful form of energy (heat or/and electricity).

The theoretical potential was calculated on the basis of Equation (3) for three poultry systems (cage, litter and free-range):

$$
E_{t h, i}=B_{i} \cdot L H V_{a r, i}
$$

The overall theoretical potential was derived as a sum of the potentials derived for the particular poultry systems, in accordance with Equation (4):

$$
E_{t h}=\sum_{i} E_{t h, i}
$$

The technical potential determined in the next part of the study was subject to limitations resulting from the availability of chicken manure. It was assumed that not all the manure generated in chicken farms was available for energy processing, taking into account both other possible treatment routs as well as energy losses due to collection, transport and storage. The second assumption limiting the amount of available manure is exclusion the free-range system manure volume from further calculations due to its negligible small amount and very large degree of terrain dispersion of free-range chicken farm.

Quantity of manure available for further energetic use was calculated as:

$$
B_{a}=\sum_{i} B_{a, i}=\sum_{i} B_{i} \cdot a_{f}
$$

The availability factor $a_{f}$ was assumed to have a value of 0.8 due to the fact that part of the available manure may be utilized in other then energy generation routs: as a soil fertiliser in crop production in large-scale agriculture, in commercial mushroom cultivation and as a granulate fertiliser on sale for commercial and non-commercial gardening. The volume of manure derived from Equation (5) was the basis for further technical potential assessment. The efficiency of the conversion from chemical energy of a raw manure (representing technical potential) into useful form of energy depends on the particular transition path. The energy generation paths adopted for analysis have been shown in Table 4.

For each of the scenarios adopted, the technical potential was then determined on the basis of assumptions concerning the efficiency of conversion of stages in a given path.

Technical potential in the particular $j$-th path of energy conversion was calculated as a sum of values derived for manure from cage and litter breeding systems, according to Equation (6)

$$
E_{\text {tech }}^{\mathrm{PATH}}=E_{\text {tech, } \text {, age }}^{\mathrm{PATH}}+E_{\text {tech,litter }}^{\mathrm{PATH}}
$$


Table 4. Analyzed chicken manure energy generation routs (scenarios).

\begin{tabular}{ccc}
\hline No. & Generation Path (Scenario) & Process Stages \\
\hline 1 & $\begin{array}{c}\text { PATH 1-Anaerobic digestion and } \\
\text { cogeneration }\end{array}$ & $\begin{array}{c}\text { I. Anaerobic (co)digestion } \\
\text { II. Heat and electricity generation in IC engine }\end{array}$ \\
\hline 2 & $\begin{array}{c}\text { PATH 2-Gasification and } \\
\text { cogeneration }\end{array}$ & $\begin{array}{c}\text { I. Drying } \\
\text { II. Gasification }\end{array}$ \\
\hline 3 & PATH 3-Combustion and & III. Heat and electricity generation in ORC unit \\
\hline 4 & cogeneration & I. Drying \\
PATH 4-Combustion & II. Fluidized-bed boiler combustion FBC \\
& & III. Heat and electricity generation in ORC unit \\
\hline
\end{tabular}

Energy potential for the conversion route based on poultry manure anaerobic digestion (PATH 1) was calculated for the particular i-th breeding systems (cage or litter) as:

$$
E_{\text {tech }, i}^{\mathrm{PATH} 1}=B_{a, i} \cdot V S_{i} \cdot b_{i} \cdot \operatorname{LH} V_{B I O, i} \cdot \eta_{t h, I C}+B_{a, i} \cdot V S_{i} \cdot b_{i} \cdot L H V_{B I O, i} \cdot \eta_{e l, I C}-E_{d, i}
$$

Equation (8) was the basis for deriving energy potential available from the gasification and ORC cogeneration technology path (PATH 2):

$$
E_{\text {tech }, i}^{\mathrm{PATH}} 2=B_{\text {dried }, i} \cdot s_{i} \cdot L H V_{s, i} \cdot \eta_{t h, \mathrm{ORC}}+B_{\text {dried }, i} \cdot s_{i} \cdot L H V_{s, i} \cdot \eta_{e l, \mathrm{ORC}}-E_{d, i}
$$

The technical potential of chicken manure in case of combustion in fluidized-bed boiler combined with ORC energy generation carried out according to PATH 3 was calculated in the following manner:

$$
E_{\text {tech }, i}^{\mathrm{PATH}} 3=B_{\text {dried }, i} \cdot \operatorname{LHV}_{\text {dried }, i} \cdot \eta_{\text {th }, \mathrm{ORC}}+B_{\text {dried }, i} \cdot \mathrm{LHV}_{\text {dried }, i} \cdot \eta_{\text {el, ORC }}-E_{d, i}
$$

The last conversion rout taken into account in the analysis is direct heat production in FCB boiler (PATH 4):

$$
E_{\text {tech }, i}^{\mathrm{PATH}} 4=B_{\text {dried }, i} \cdot L H V_{\text {dried }, i} \cdot \eta_{t h}-E_{d, i}
$$

In case of energy conversion paths that require drying the manure before further processing (PATH 2, PATH 3 and PATH 4), the amount of energy $E_{d}$ used for water evaporation from manure depends on dryer efficiency resulting from specific heat and electricity demands of drying process:

$$
E_{d, i}=B_{w, i} \cdot q+B_{w, i} \cdot e
$$

$q$ : specific heat demand for drying, $\mathrm{kWh} \cdot \mathrm{kg}^{-1}$ of evaporated water

$e$ : specific electricity demand for drying, $\mathrm{kWh}^{-1}$ of evaporated water

The amount of water $B_{w}$ evaporated from available raw manure $B_{a}$ depends on moisture content in manure before drying $M_{t w}$ and required moisture content after drying process $M_{t w, a d}$, according to Equation (12):

$$
B_{w, i}=M_{t w} \cdot B_{a, i}-M_{t w, a d} \cdot B_{d r i e d, i}
$$

where the volume of the material after drying $B_{\text {dried }}$ was determined from the mass balance of the drying process.

Set of the input data used for further assessment of technical potential can be found in Table 5 . 
Table 5. Input data for technical potential calculation according to assumed conversion paths.

\begin{tabular}{|c|c|c|c|}
\hline \multirow{2}{*}{ Parameter } & \multirow{2}{*}{ Unit } & \multicolumn{2}{|c|}{ Value } \\
\hline & & Cage Manure & Litter Manure \\
\hline \multicolumn{4}{|c|}{ PATH 1} \\
\hline$V S$ & \% by weight & 84.4 & 88.0 \\
\hline$b$ & $\mathrm{~m}^{3} \cdot \mathrm{Mg}^{-1}$ of $\mathrm{VS}$ & 300 & 270 \\
\hline$L H V_{B I O}$ & $\mathrm{MJ} \cdot \mathrm{m}^{-3}$ & 20 & 20 \\
\hline$\eta_{t h, I C}$ & - & 0.50 & 0.50 \\
\hline$\eta_{e l, I C}$ & - & 0.38 & 0.38 \\
\hline \multicolumn{4}{|c|}{ PATH 2} \\
\hline$M_{t w}$ & $\%$ by weight & 70.9 & 18.1 \\
\hline$M_{t w, a d}$ & $\%$ by weight & 15.0 & 15.0 \\
\hline$q$ & $\mathrm{kWh} \cdot \mathrm{kg}^{-1}$ of evaporated water & 0.90 & 0.90 \\
\hline$e$ & $\mathrm{kWh} \cdot \mathrm{kg}^{-1}$ of evaporated water & 0.08 & 0.08 \\
\hline$s$ & $\mathrm{~m}^{3} \cdot \mathrm{kg}^{-1}$ of dried mass input & 2.5 & 2.5 \\
\hline$L H V_{s}$ & $\mathrm{MJ} \cdot \mathrm{m}^{-3}$ & 3.5 & 4.5 \\
\hline$\eta_{t h, \text { ORC }}$ & - & 0.7 & 0.7 \\
\hline$\eta_{e l, O R C}$ & - & 0.18 & 0.18 \\
\hline \multicolumn{4}{|c|}{ PATH 3} \\
\hline$M_{t w}$ & $\%$ by weight & 70.9 & 18.1 \\
\hline$M_{t w, a d}$ & $\%$ by weight & 35 & 18.1 \\
\hline$q$ & $\mathrm{kWh} \cdot \mathrm{kg}^{-1}$ of evaporated water & 0.90 & - \\
\hline$e$ & $\mathrm{kWh} \cdot \mathrm{kg}^{-1}$ of evaporated water & 0.08 & - \\
\hline$L H V_{\text {dried }}{ }^{*}$ & $\mathrm{MJ} \cdot \mathrm{Mg}^{-1}$ & 3201 & 7728 \\
\hline$\eta_{t h, O R C}$ & - & 0.7 & 0.7 \\
\hline$\eta_{e l, O R C}$ & - & 0.18 & 0.18 \\
\hline \multicolumn{4}{|c|}{ PATH 4} \\
\hline$M_{t w}$ & $\%$ by weight & 70.9 & 18.1 \\
\hline$M_{t w, a d}$ & \% by weight & 15.0 & 18.1 \\
\hline$q$ & $\mathrm{kWh} \cdot \mathrm{kg}^{-1}$ of evaporated water & 0.90 & - \\
\hline$e$ & $\mathrm{kWh} \cdot \mathrm{kg}^{-1}$ of evaporated water & 0.08 & - \\
\hline$L H V_{\text {dried }}{ }^{*}$ & $\mathrm{MJ} \cdot \mathrm{Mg}^{-1}$ & 3201 & 7728 \\
\hline$\eta_{t h}$ & - & 0.85 & 0.87 \\
\hline
\end{tabular}

\section{Results and Discussion}

\subsection{Quantitative Potential}

In accordance with the adopted assumptions, the annual production of chicken manure from different rearing system was determined and presented in Table 6.

The annual laying hens manure production equals to 2165 thousand $\mathrm{Mg}$ while volume of broiler manure is around 2330 thousand $\mathrm{Mg}$. This corresponds to the total annual chicken manure production of 4495 thousand $\mathrm{Mg}$. Considering the weight of chicken manure depending on the rearing system, the amount of manure from the cage system is smaller than the one from litter, and is around 1831 thousand Mg compared to 2602 thousand Mg from litter (laying hens and broilers).

The results of quantitative chicken manure potential assessment analysis have been linked with geographic data with use of a GIS based method implemented in QGIS software [34]. The map generated with this free and open source Geographic Information System is presented in Figure 4. 
Table 6. Annual chicken (laying hens and broilers) manure production, in $\mathrm{Mg}$.

\begin{tabular}{cccccc}
\hline \multirow{2}{*}{ Province } & \multicolumn{3}{c}{ Laying Hens } & Broilers & \multirow{2}{*}{ Overall } \\
& Chickens \\
\cline { 2 - 4 } & Cage & Litter & Free-Range & Litter & Che \\
\hline Dolnoślaskie (I) & 78,280 & 19,125 & 2726 & 65,233 & 165,364 \\
Kujawsko-Pomorskie (II) & 67,717 & 10,472 & 2325 & 185,399 & 265,913 \\
Lubelskie (III) & 65,549 & 16,262 & 4043 & 84,192 & 170,046 \\
Lubuskie (IV) & 48,031 & 2202 & 434 & 65,233 & 115,900 \\
ódzkie (V) & 82,625 & 11,774 & 5187 & 177,495 & 277,081 \\
Małopolskie (VI) & 84,596 & 20,034 & 1983 & 46,595 & 153,209 \\
Mazowieckie (VII) & 379,381 & 38,905 & 13,474 & 514,872 & 946,632 \\
Opolskie (VIII) & 13,563 & 21,937 & 1522 & 60,572 & 97,593 \\
Podkarpackie (IX) & 68,215 & 16,968 & 1309 & 62,902 & 149,395 \\
Podlaskie (X) & 24,761 & 31,868 & 691 & 212,007 & 269,326 \\
Pomorskie (XI) & 59,486 & 8,385 & 2232 & 80,072 & 150,176 \\
Ślaskie (XII) & 64,043 & 31,633 & 791 & 116,241 & 212,708 \\
Swiętokrzyskie (XIII) & 43,703 & 4003 & 8154 & 79,211 & 135,072 \\
Warmińsko-Mazurskie (XIV) & 36,693 & 960 & 1168 & 68,190 & 107,012 \\
Wielkopolskie (XV) & 673,472 & 25,603 & 11,644 & 324,019 & $1,034,737$ \\
Zachodniopomorskie (XVI) & 40,792 & 12,439 & 3854 & 187,389 & 244,474 \\
Poland-overall & $1,830,908$ & 272,570 & 61,538 & $2,329,623$ & $4,494,639$ \\
\hline
\end{tabular}

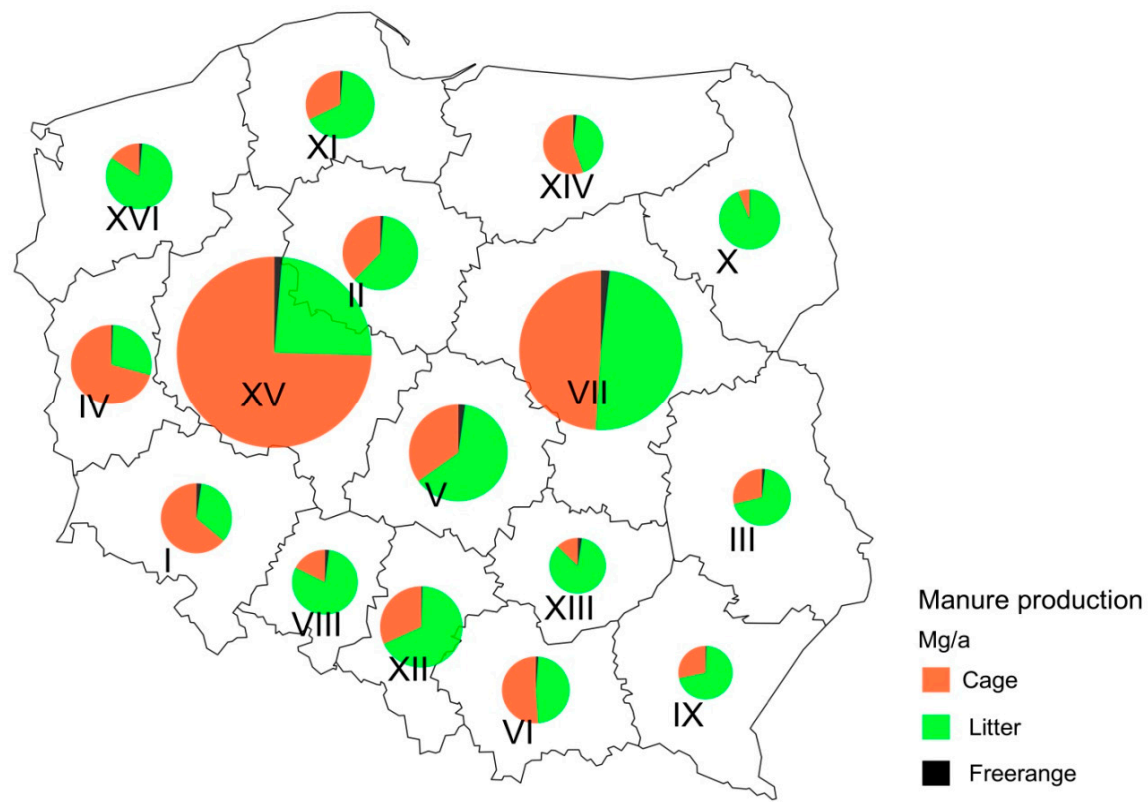

Figure 4. Annual chicken manure potential from various rearing systems in provinces of Poland.

\subsection{Theoretical Qualitive Potential}

The value of the theoretical energy potential for the particular provinces in Poland was derived with use of presented methodology and on the basis of input data of the quantitative potential of chicken manure in Poland (Section 3.1) and results of proximate, ultimate and heating value analyses (Section 2.2.1). The results of the calculations are summarized in Table 7. In addition, the technical potential has been presented in Figure 5 with use of QGIS software (3.4, Free Software Foundation, Boston, MA, USA). 
Table 7. Annual theoretical energy potential of chicken manure in Poland, $E_{t h}$ in TJ.

\begin{tabular}{ccccc}
\hline Province & Cage & Litter & Free-Range & Total \\
\hline Dolnośląskie (I) & 250.6 & 1112.6 & 8.9 & 1372.1 \\
Kujawsko-Pomorskie (II) & 216.8 & 2583.3 & 7.6 & 2807.7 \\
Lubelskie (III) & 209.8 & 1324.9 & 13.2 & 1547.9 \\
Lubuskie (IV) & 153.7 & 889.4 & 1.4 & 1044.6 \\
ódzkie (V) & 264.5 & 2496.3 & 16.9 & 2777.7 \\
Małopolskie (VI) & 270.8 & 878.8 & 6.5 & 1156.0 \\
Mazowieckie (VII) & 1214.4 & 7303.8 & 44.0 & 8562.1 \\
Opolskie (VIII) & 43.4 & 1088.2 & 5.0 & 1136.6 \\
Podkarpackie (IX) & 218.4 & 1053.4 & 4.3 & 1276.0 \\
Podlaskie (X) & 79.3 & 3216.5 & 2.3 & 3298.0 \\
Pomorskie (XI) & 190.4 & 1166.7 & 7.3 & 1364.4 \\
Śląskie (XII) & 205.0 & 1950.3 & 2.6 & 2157.9 \\
Świętokrzyskie (XIII) & 139.9 & 1097.5 & 26.6 & 1264.0 \\
Warmińsko-Mazurskie (XIV) & 117.5 & 912.0 & 3.8 & 1033.3 \\
Wielkopolskie (XV) & 2155.8 & 4611.2 & 38.0 & 6804.9 \\
Zachodniopomorskie (XVI) & 130.6 & 2635.5 & 12.6 & 2778.7 \\
Poland-overall & 5860.7 & $34,320.3$ & 200.7 & $40,381.8$ \\
\hline
\end{tabular}

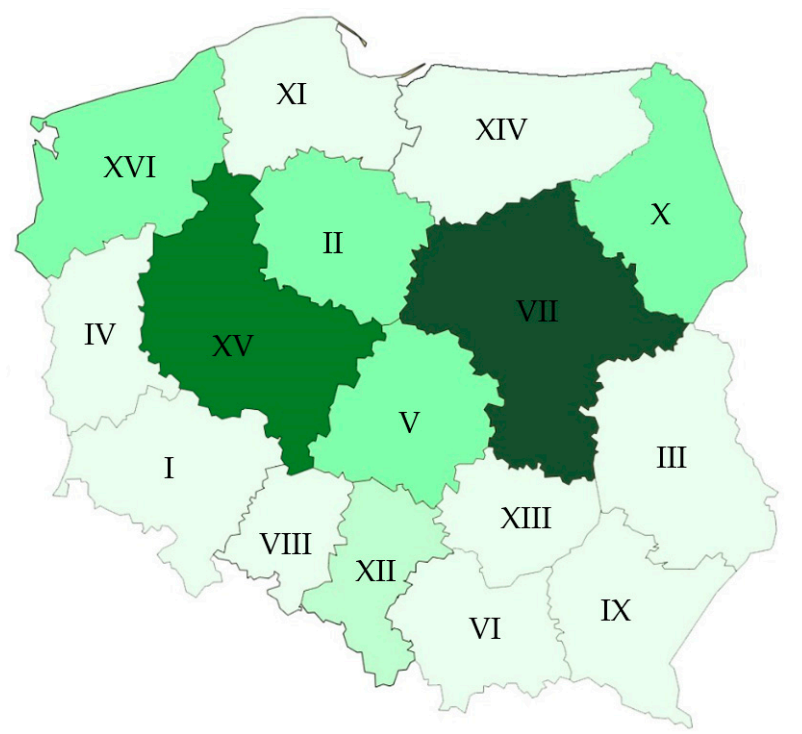

Theoretical potential $E_{t h}$ $\mathrm{TJ} \cdot \mathrm{a}^{-1}$

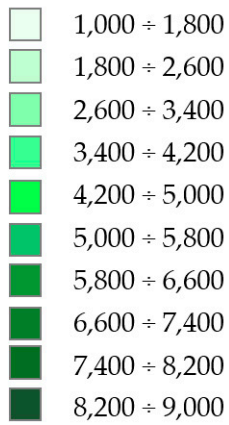

Figure 5. Energy potential of chicken manure in provinces in Poland derived on the theoretical level.

Total energy potential of chicken manure assessed for Poland equals $40,382 \mathrm{TJ} \cdot \mathrm{a}^{-1}$, including three analyzed rearing systems. Manure from the cage system has biggest potential: more then $34,200 \mathrm{TJ} \cdot \mathrm{a}^{-1}$ which is close to $85 \%$ of overall chicken manure potential. Cage system provides wastes for less than $15 \%$ of total potential, whereas free-range rearing system generates manure has negligible share: hardly $0.5 \%$. The highest chicken manure energy resources have been determined in Mazowieckie (VII) and Wielkopolskie (XV) provinces. They constitute almost $40 \%$ of the country's potential.

\subsection{Thechnical Qualitive Potential}

According to common classification of the energy potential, the next step in assessing the potential should be connected with the technical task of determining the efficiency of converting chemical energy of the fuel to useful forms of energy [35]. Within the research, the technical energy potential of two types of chicken manure (from cage and litter systems) has been determined according to four chosen conversion scenarios. It has been assumed that the energy generated in each scenario is in form of heat or heat and electricity in combined manner. Results of the calculation are shown in Table 8. 
Table 8. Annual technical energy potential of chicken manure in Poland overall, $E_{t e c h}$ in TJ.

\begin{tabular}{cccccccc}
\hline \multirow{2}{*}{$\begin{array}{c}\text { Generation } \\
\text { Scenario }\end{array}$} & \multicolumn{2}{c}{ Cage System } & \multicolumn{2}{c}{ Litter System } & \multicolumn{2}{c}{ Total } & \multirow{2}{*}{$\begin{array}{c}\text { Overall } \\
\text { Potential }\end{array}$} \\
\cline { 2 - 6 } & Heat & Electricity & Heat & Electricity & Heat & Electricity & \\
\hline PATH 1 & 1079 & 820 & 4051 & 3899 & 5130 & 3899 & 9029 \\
PATH 2 & 1632 & 651 & 15,682 & 4051 & 17,315 & 4702 & 22,017 \\
PATH 3 & 2339 & 796 & 19,220 & 4942 & 21,559 & 5738 & 27,297 \\
PATH 4 & 3099 & 0 & 23,888 & 0 & 26,987 & 0 & 26,987 \\
\hline
\end{tabular}

On the basis of the results presented in Table 8 it can be claimed that the biggest technical energy potential of chicken manure was achieved via the PATH 3 and PATH 4 conversion routes, where after drying, the manure was utilized in FBC combustor. Thereafter output heat is supplying ORC unit for electricity and useful heat generation (PATH 3) or is being directly transformed into useful heat flux (PATH 4). Relatively low potential was found for anaerobic digestion scenario (PATH 1) where overall energy production was from around $33 \%$ of the potential gained in PATH 4 to $41 \%$ of the PATH 2 potential. Significantly lower production of energy from poultry manure by anaerobic digestion compared to gasification process was noticed by Chang [36] who reported $44.5 \%$ higher energy production in syngas than that in biogas.

An additional summary of the results achieved in the research is presented in Figure 6. It can be observed that technical potential of the chicken manure is much smaller than technical one, regardless of the analyzed conversion path. It is mainly due to availability of manure assumed for the calculation (availability factor $a_{f}=0.8$ ) as well as efficiency of energy transformation through the particular stages in the assumed scenarios.

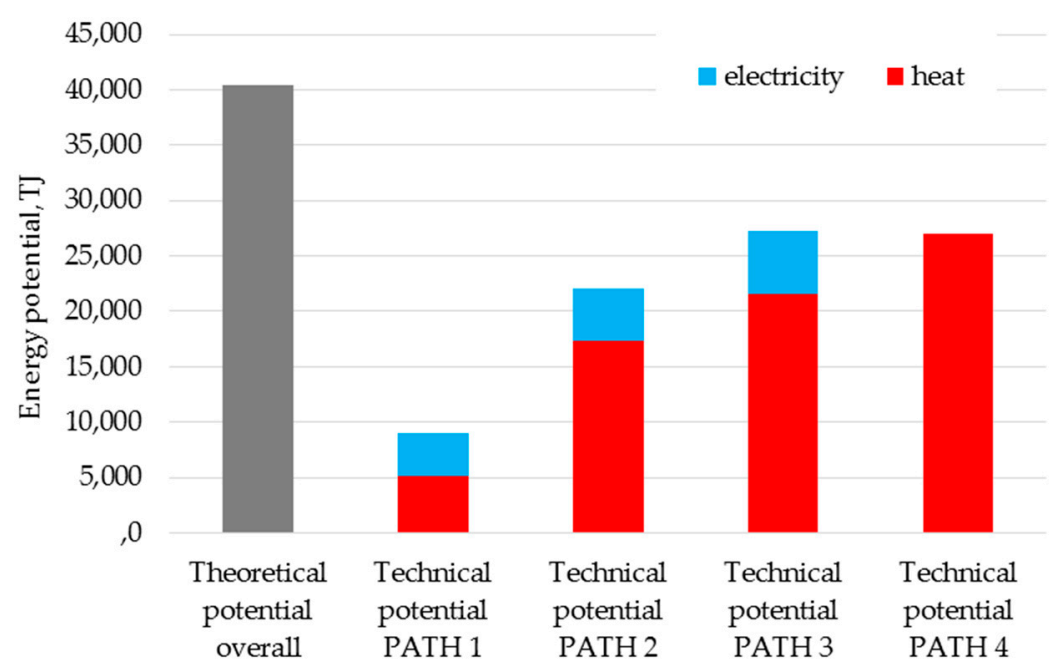

Figure 6. Energy potential of chicken manure determined for Poland according to different technical scenarios.

As shown in Figure 7, for theoretical and technical level of determined energy potential, the share of manure from the litter system is significantly high (between $79 \%$ and $89 \%$ ) in comparison to the quantitative potential of raw manure (near 59\%). Despite the fact that the amount of manure from the cage systems is not much smaller than the amount of manure gained from litter systems (41.3\%:58.7\%), the litter manure has a much greater potential for generation of useful energy. When comparing the individual paths, the highest cage share was recorded for anaerobic digestion route (PATH 1). Both the gasification pathway (PATH 2) and the combustion pathways (PATH 3 and PATH 4) are quite similar for both analyzed types of manure. 


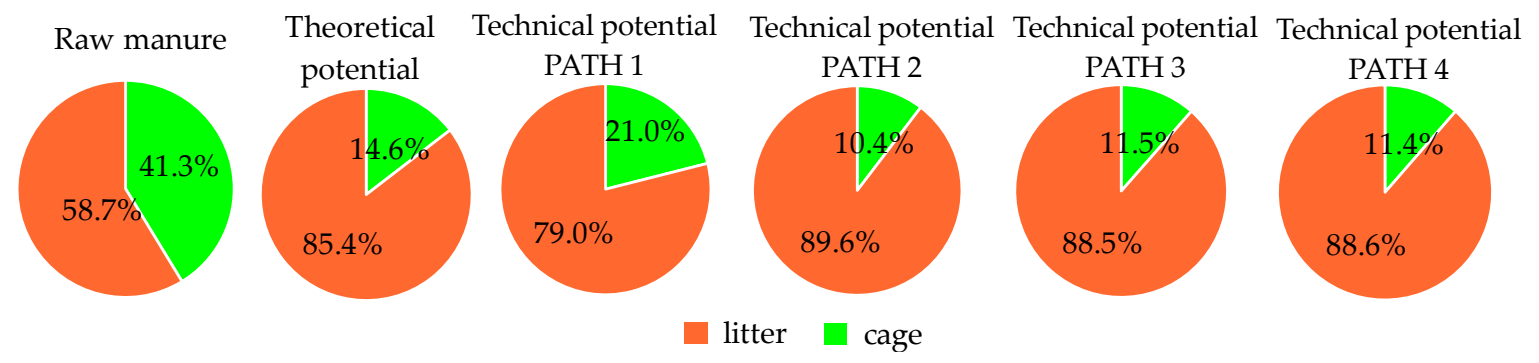

Figure 7. The contribution of particular types of manure in the determined energy potential.

\subsection{Technical and Environmental Issues of Proposed Energy Generation Routes}

The use of technologies adopted for estimating the technical potential of chicken manure in particular energy conversion paths requires additional discussion on the technical and environmental aspects of their application.

The chicken manure is a special type of substrate for biogas plants, due to the high content of organic substances, which through the anaerobic digestion generates biogas and biofertiliser as a by-product. The use of poultry manure as a substrate in agricultural biogas plants causes operational problems, mainly due to high concentrations of ammonium nitrogen and unfavourable ratio of organic carbon to nitrogen [37]. Therefore, proper methane fermentation of poultry manure requires balancing of $C / N$ ratio, e.g., by introducing an appropriate amount of $C$-rich co-substrate. Dilution the chicken manure with water is a basic option to eliminate the effect of $\mathrm{NH}_{3}-\mathrm{N}$ on bio-digestion inhibition. Unfortunately, the dilution increases volume of waste and declines feasibility of the method [6]. Another manners to overcome the ammonia inhibition are addition of phosphorite ore to the raw manure or implementation of air stripping technology [37]. The utility of the anaerobic digestion is also limited by the presence of hydrogen sulfide $\left(\mathrm{H}_{2} \mathrm{~S}\right)$ in biogas. $\mathrm{H}_{2} \mathrm{~S}$ has highly corrosive properties, therefore effective desulphurization of biogas before further thermal processing is required [36].

Thermochemical conversion of the poultry waste through the gasification generates syngas with calorific values significantly lower compared to the biogas, however the energy yields from gasification is much higher than from digestion. The quality of syngas and residues is mainly influenced by the type of gasification agent (air, steam or carbon dioxide), reactor configuration and operating parameters, mainly temperature and air equivalence ratio [38]. Among commonly used systems, usually fixed and fluidized bed reactors are used for chicken manure gasification purposes. The updraft fixed bed systems are preferable for fuels such as chicken manure due to its tolerance on high moisture and ash content as well as low sensitivity to fuel size and quality [38]. Nevertheless, this technology has several disadvantages, which should be considered prior to the possible application. These disadvantages include content of undesirable by-products such as tar, dust, alkalis, heavy metals, $\mathrm{H}_{2} \mathrm{~S}$ and $\mathrm{HCl}$, which should be reformed, in particular, when the syngas is considered as a fuel to supply the gas turbines and IC engines. The essential difficulty in the manure gasification is the high alkali content in the ash leading to its agglomeration in the bed [39]. Attempts to prevent the phenomenon of agglomeration, by lowering the temperature in the reactor (below the ash melting point), decrease conversion efficiency and lead to the formation of excessive amounts of char.

In case of combustion pathway, the greatest drawback is associated with the large moisture and ash content in the manure, which may cause operational problems and decrease overall efficiency. Hence, drying raw manure is necessary to reduce the mass of manure and make it more suitable for further thermal processing such as combustion or gasification. The moisture content can be reduced through the use of various evaporative dryer technologies [40], integrated within the ventilation and manure transport system on the chicken farm (e.g., manure draying tunnels MDT) or being a part of the combustion system. Drying the manure on site by utilizing the exhaust air from livestock facilities significantly cuts the costs of energy required for drying process. The ash in the manure contains high amount of alkaline elements, particularly $\mathrm{K}$ and $\mathrm{Na}$ oxides, which leads to formation of 
low-temperature melting compounds and eutectics causing the probability of fouling and slagging [41]. High-ash poultry manure combustion may have a negative impact on the operation of boilers by its agglomeration in the bed, formation of deposits in the freeboard zone and fouling of the boiler hot surfaces and ancillary equipment [5]. Moreover, the presence of the fuel bound-Cl element increases the additional risk of high-temperature corrosion evaluation on boiler surfaces. The corrosive damages are caused by molecular chlorine-product of oxidation of hydrogen chloride contained in hot gases, as well as alkaline chlorides, formed as a result of binding with alkaline elements ( $\mathrm{K}$ and Na oxides). Intensive research is currently being carried out to counteract these negative phenomena [5]. Another issue worth considering in case of chicken manure combustion is $\mathrm{NO}_{\mathrm{x}}$ formation as the major air pollutant. Application of combustion technologies based on the fluidized bed combustion (FBC) can be solution to solve this disadvantage [31]. $\mathrm{NO}_{\mathrm{x}}$ reduction in this technology is related to lowering the combustion temperature, obtaining uniform temperature distribution in the chamber and appropriate fuel to air ratio (excess air ratio). Furthermore, the high sulphur and volatile matter content in the manure forces a suitable composition of the fuel-air mixture in the boiler to ensure both high efficiency and low emissions of harmful pollutants. The composition of manure fuel requires not only the use of primary reduction methods, but also applications of systems for the intensive gases cleaning, i.e., the selective catalytic reduction (SCR) for denitrification, sorption for the removal of acid gases $\left(\mathrm{SO}_{2}, \mathrm{HCl}\right)$ and electrostatic technique for dedusting. These techniques are usually used in large plants, but can also be applied in small combustion/cogeneration units to meet emission standards [42]. Under Polish conditions, application of any optimized manure combustion technology is an interesting alternative to coal-based heat and electricity generation, in particular on poultry farms where heat is generated with use of fossil fuels. Compared to combustion of coal, it can reduce significantly the emissions of flue gas components into the atmosphere, as shown by [5].

\section{Conclusions}

The research reported in the paper is dedicated to assessing the theoretical and technical energy potential of chicken manure in the particular provinces of Poland. The conducted analyses resulted in deriving the value of this potential on the basis of collected data of annual chicken manure generation as well as its physicochemical properties. The volume of the theoretical potential is promising in the context of its utilization as a source of chemical energy of the fuel useful for producing heat and electricity directly on sites where chickens are reared. Conversion of chicken waste feedstock into useful form of energy has a great potential for improving the environmental sustainability of poultry production. Taking into account the fact that the energy supplying chicken farm in Poland comes mainly from coal, the use of the manure on site for heat or/and electricity generation is all the more valuable.

The volume of chicken manure in Poland is estimated at 4.49 million tons, of which the cage system accounts for $40.7 \%$, while the litter one accounts for $57.9 \%$. Chicken manure from the free-range system is responsible for only $1.4 \%$ of poultry production and can be neglected regarding its energy potential. The majority of chicken manure is generated in Wielkopolskie and Mazowieckie provinces, which account for $44 \%$ of the total production of this material in Poland. The volume of chicken manure does not translate directly into the potential in terms of various physicochemical properties of manure in the analysis poultry systems. The total volume of theoretical energy potential is equal to 40.38 PJ per year.

It should be emphasized that energy potential of chicken manure derived at theoretical level disregards the loss of energy conversion in facilities used for manure conditioning (drying) as well as energy losses during production of useful energy (e.g., heat). The relevant analysis of determination of technical energy potential of chicken manure in Poland was conducted for four different energy conversion paths. Determined technical potential occurred significantly smaller then theoretical. Its value ranged from 9.01 PJ per year to 27.3 PJ per year. The bigger energy degradation was found for 
heat and electricity production via anaerobic digestion path, while fluidized bed combustion occurred the most efficient scenario.

In addition, on the basis of the analysis carried out within the presented research, it should be concluded that the choice of an appropriate pathway for energetic conversion of manure use should be adapted to its availability and physicochemical parameters.

Author Contributions: Conceptualization, M.T. and R.J.; methodology, M.T. and R.J.; software, M.T. and A.K.-W.; validation, A.K.-W.; formal analysis, R.J.; investigation, M.T. and R.J.; resources, M.T., R.J. and P.N.; data curation, P.N.; writing — original draft preparation, M.T. and R.J.; writing—review and editing, M.T.; visualization, M.T.; supervision, M.T. and R.J.

Funding: This research received no external funding.

Acknowledgments: The authors are grateful for the support of the company Ferma Drobiu Trzy Koguty Sp. z o.o. which provided chicken manure for the research.

Conflicts of Interest: The authors declare no conflict of interest.

\section{Abbreviations}

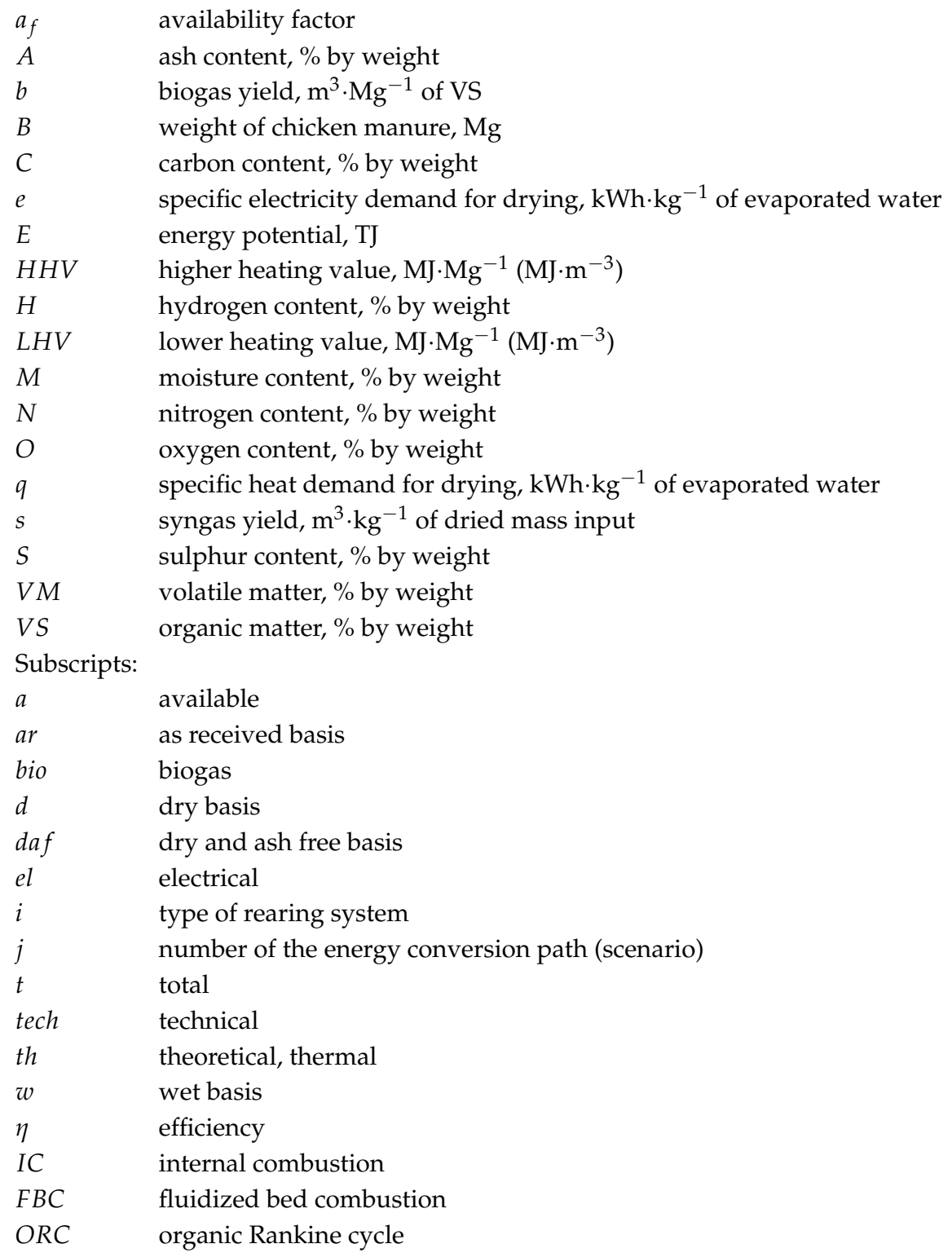




\section{References}

1. Saidura, R.; Abdelaziza, E.A.; Demirbasb, A.; Hossaina, M.S.; Mekhilefc, S. A review on biomass as a fuel for boilers. Renew. Sustain. Energy Rev. 2011, 15, 2262-2289. [CrossRef]

2. Qian, X.; Lee, S.; Soto, A.-M.; Chen, G. Regression Model to Predict the Higher Heating Value of Poultry Waste from Proximate Analysis. Resources 2018, 7, 39. [CrossRef]

3. Dalólio, F.S.; Nogueira da Silva, J.; Carneiro de Oliveira, A.C.; Ferreira Tinôco, I.F.; Barbosa, R.C.; Resende, M.O.; Teixeira Albino, L.F.; Teixeira Coelho, S. Poultry Litter as Biomass Energy: A Review and Future Perspectives. Renew. Sustain. Energy Rev. 2017, 76, 941-949. [CrossRef]

4. Wieremiej, W. Usefulness of Poultry Wastes in Fertilization of Maize (Zea mays L.) and Their Influence on Selected Soil Properties (In Polish). Ph.D. Thesis, Siedlce University of Natural Sciences and Humanities, Siedlce, Poland, 30 March 2017.

5. Billen, P.; Costa, J.; Van der Aa, L.; Van Caneghem, J.; Vandecasteele, C. Electricity from poultry manure: A cleaner alternative to direct land application. J. Clean. Prod. 2015, 96, 467-475. [CrossRef]

6. Kelleher, B.P.; Leahy, J.J.; Henihan, A.M.; O’Dwyer, T.F.; Sutton, D.; Leahy, M.J. Advances in poultry litter disposal technology: A review. Bioresour. Technol. 2002, 83, 27-36. [CrossRef]

7. Florin, N.H.; Maddocks, A.R.; Wood, S.; Harris, A.T. High-temperature thermal destruction of poultry derived wastes for energy recovery in Australia. Waste Manag. 2019, 24, 1399-1408. [CrossRef] [PubMed]

8. Cantrell, K.B.; Hunt, P.G.; Uchimiya, M.; Novak, J.M.; Ro, K.S. Impact of pyrolysis temperature and manure source on physicochemical characteristics of biochar. Bioresour. Technol. 2012, 107, 419-428. [CrossRef]

9. Tańczuk, M.; Junga, R.; Werle, S.; Chabiński, M.; Ziółkowski, . Experimental analysis of the fixed bed gasification process of the mixtures of the chicken manure with biomass. Renew. Energy Rev. 2019, 136, 1055-1063. [CrossRef]

10. Reardon, J.P.; Lilley, A.; Brown, K.; Beard, K.; Wimberly, J.; Avens, J. Demonstration of a Small Modular Biopower System Using Poultry Litter; DOE SBIR Phase-I Final Report; Community Power Corporation: Englewood, CO, USA, 2001. Available online: https:/ / www.osti.gov/servlets/purl/794292/ (accessed on 12 December 2018).

11. European Egg Processors Association. EU Statistics. Available online: http://www.eepa.info/Statistics.aspx (accessed on 12 November 2018).

12. Food and Agriculture Organization of the United Nations. FAOSTAT. Available online: http://www.fao. org/faostat/en/\#data/QA (accessed on 12 November 2018).

13. International Energy Agency. Energy Policies of IEA Countries, Poland 2016 Review; IEA Publications: Paris, France, 2017; ISBN 978-92-64-27230-9.

14. Tańczuk, M.; Radziewicz, W.; Olszewski, E.; Skorek, J. Projected configuration of a coal-fired district heating source on the basis of comparative technical-economical optimization analysis. In Proceedings of the International Conference on Energy, Environment and Material Systems (EEMS), E3S Web of Conferences, Polanica Zdrój, Poland, 13-15 September 2017; Volume 19. [CrossRef]

15. Tańczuk, M.; Masiukiewicz, M.; Anweiler, S.; Junga, R. Technical Aspects and Energy Effects of Waste Heat Recovery from District Heating Boiler Slag. Energies 2018, 11, 796. [CrossRef]

16. Batidzirai, B.; Smeets, E.M.W.; Faaij, A.P.C. Harmonising bioenergy resource potentials: Methodological lessons from review of state of the art bioenergy potential assessments. Renew. Sustain. Energy Rev. 2012, 16, 6598-6630. [CrossRef]

17. Gonzalez-Salazara, M.A.; Morini, M.; Pinelli, M.; Spina, P.R.; Venturini, M.; Finkenrath, M.; Poganietz, W.R. Methodology for estimating biomass energy potential and its application to Colombia. Appl. Energy 2014, 136, 781-796. [CrossRef]

18. Lourinho, G.; Brito, P. Assessment of biomass energy potential in a region of Portugal (Alto Alentejo). Energy 2015, 81, 189-201. [CrossRef]

19. Nadel, S.; Shipley, A.M.; Elliott, R.N. The Technical, Economic and Achievable Potential for Energy Efficiency in the United States: A Meta-Analysis of Recent Studies; American Council for Energy-Efficient Economy (ACEEE): Washington, DC, USA, 2004.

20. Karaj, S.; Rehl, T.; Leis, H.; Müller, J. Analysis of biomass residues potential for electrical energy generation in Albania. Renew. Sustain. Energy Rev. 2010, 14, 493-499. [CrossRef]

21. Tańczuk, M.; Ulbrich, R. Assessment of energetic potential of biomass. Proc. ECOpole 2009, 3, $23-26$. 
22. Main Veterinary Inspectorate. Registers and Records Kept in Main Veterinary Inspectorate (In Polish). Available online: https: / www.wetgiw.gov.pl/handel-eksport-import/rejestr-podmiotow-prowadzacychdzialalnosc-nadzorowana (accessed on 12 November 2018).

23. Statistics Poland. Farm Animals in 2017. Available online: http://stat.gov.pl/en (accessed on 12 November 2018).

24. Dobrzański, Z. The Relationship between Modern Poultry Production Systems and the Protection of Natural and Productive Environment (In Polish). First Agricultural Portal. 2002. Available online: http:/ /www.ppr. pl/artykul-ppr-2924.php?_resourcePK=2924 (accessed on 7 November 2018).

25. Mayoral, M.C.; Izquierdo, M.T.; Andrés, J.M.; Rubio, B. Different approaches to proximate analysis by thermogravimetry analysis. Thermochim. Acta 2001, 370, 91-97. [CrossRef]

26. Quiroga, G.; Castrillón, L.; Fernández-Nava, Y.; Marańón, E. Physico-chemical analysis and calorific values of poultry manure. Waste Manag. 2010, 30, 880-884. [CrossRef]

27. Staroń, P.; Kowalski, Z.; Staron, A.; Banach, M. Thermal conversion of granules from feathers, meat and bone meal and poultry litter to ash with fertilizing properties. Agric. Food Sci. 2017, 26, 173-180. [CrossRef]

28. Lynch, D.; Henihan, A.M.; Bowen, B.; Lynch, D.; McDonnell, K.; Kwapinski, W.; Leahy, J.J. Utilisation of poultry litter as an energy feedstock. Biomass BioEnergy 2013, 49, 197-204. [CrossRef]

29. Trziszka, T. Jajczarstwo: Nauka, Technologia, Praktyka; Wydawnictwo Akademii Rolniczej we Wrocławiu: Wrocław, Poland, 2000.

30. Polesek-Karczewska, S.; Turzyński, T.; Kardaś, D.; Heda, . Front velocity in the combustion of blends of poultry litter with straw. Fuel Process. Technol. 2018, 176, 307-315. [CrossRef]

31. Toptas, A.; Yildrim, Y.; Duman, G.; Yanik, Y. Combustion behavior of different kinds of torrefied biomass and their blends with lignite. Bioresour. Technol. 2015, 177, 328-336. [CrossRef]

32. Yurdakul, S. Determination of co-combustion properties and thermal kinetics of poultry litter/coal blends using thermogravimetry. Renew. Energy 2016, 89, 215-223. [CrossRef]

33. Whitely, N.; Ozao, R.; Artiaga, R.; Cao, Y.; Pan, W.P. Multi-utilization of chicken litter as biomass source. Part I. Combustion. Energy Fuel 2006, 20, 2660-2665. [CrossRef]

34. QGIS-A Free and Open Source Geographic Information System. Available online: https:/ /www.qgis.org/ (accessed on 23 January 2019).

35. Oliveira, M.O.; Somariva, R.; Ando Junior, O.H.; Neto, J.M.; Bretas, A.S.; Perrone, O.E.; Reversat, J.H. Biomass Electricity Generation Using Industry Poultry Waste. In Proceedings of the International Conference on Renewable Energies and Power Quality (ICREPQ'12), Santiago de Compostela, Spain, 28-30 March 2012; pp. 1650-1654.

36. Chang, F.H. Energy and sustainability comparisons of anaerobic digestion and thermal technologies for processing animal waste. In Proceedings of the 2004 ASAE Annual Meeting, Ottawa, ON, Canada, 1-4 August 2004.

37. Singh, K.; Lee, K.; Worley, J.; Risse, L.M.; Das, K.C. Anaerobic digestion of poultry litter: A review. Appl. Eng. Agric. 2010, 26, 677-688. [CrossRef]

38. Watson, J.; Zhang, Y.; Si, B.; Chen, W.-T.; de Souza, R. Gasification of biowaste: A critical review and outlooks. Renew. Sustain. Energy Rev. 2018, 83, 1-17. [CrossRef]

39. Taupe, N.; Lynch, D.; Wnetrzak, R.; Kwapinska, M.; Kwapinski, W.; Leahy, J. Updraft gasification of poultry litter at farm-scale-A case study. Waste Manag. 2016, 50, 324-333. [CrossRef]

40. Brammer, J.G.; Bridgwater, A.V. Drying technologies for an integrated gasification bio-energy plant. Renew. Sustain. Energy Rev. 1999, 3, 243-289. [CrossRef]

41. Lynch, D.; Henihant, A.M.; Kwapinski, W.; Zhang, L.; Leahy, J. Ash agglomeration and deposition during combustion of poultry litter in a bubbling fluidized-bed combustor. Energy Fuels 2013, 27, 4684-4694. [CrossRef]

42. Commission Regulation (EU) No 592/2014 of 3 June 2014 Amending Regulation (EU) No 142/2011 as Regards the Use of Animal by-Products and Derived Products as a Fuel in Combustion Plants. Available online: https:eur-lex.europa.eu/ (accessed on 12 January 2019).

(C) 2019 by the authors. Licensee MDPI, Basel, Switzerland. This article is an open access article distributed under the terms and conditions of the Creative Commons Attribution (CC BY) license (http:/ / creativecommons.org/licenses/by/4.0/). 